\title{
ELT Descriptive Hypothesis
}

\author{
Tagor Pangaribuan \\ English Language Education - Faculty of Teacher Trainning \\ Universitas HKBP Nommensen Medan \\ Medan, Indonesia \\ e-mail:tagorp52@yahoo.com
}

\author{
Kammer Tuahman Sipayung \\ English Language Education-Faculty of Teacher Trainning \\ Universitas HKBP Nommensen Medan \\ Medan, Indonesia \\ e-mail:Kammertuahmansipayung@gmail.com
}

\begin{abstract}
Teaching is an epitome. It is the core of intellectual gain as truth. A teacher learns learning by doing and doing by learning. The purpose is to find out acts of empowerment, its effectiveness as revitalization and reinforcement through ELT classroom acts. The research methodology is an experimental designin a four months ongoing semester2017-2018, three experimental groups and one control groups with 146 subjects. The data are collected through teacher performances in microteaching class, scored based on defined categories. This research shows that there is a significant difference between preassessment and post test in each teaching narrative episodes of teaching stages, between experiment groups and control groups. The experimental groups shows better performnces in realizing ELT generic skills, indesigning and assessing their descriptive hypothesis. However, hard-time services of pedagogic acts for realizing better classroom praxis are replication is recommended on generic skills, ELT and lectures.
\end{abstract}

Keywords- ELT, Generic Teaching Skills, Descriptive Hypothesis, scientific teaching

\section{INTRODUCTION}

Teaching is doing learning. In one view, it is a classroom world. In the other, it deals with future challenges, how intellects help solve problems. It is the essence of teaching. The nature of the entity, its simplicity and its complex demand is generic. This research underline similar assumption in a goal-means-end analysis, and propose epitome as meaning (sentencia) in the form of speech act in relevant contexts and situations. They are generic English skills as performance for the learner to aquire.

In the treatment of this topic, no specific reference to Asia is made since the debate is relevant in all contexts. The focus of [1] research is to identify valuable considerations to improve teaching strategies and methods however this study's focus on teaching technique, method and descriptive hypothesis. In addition to that, this study focuse on developing generic teaching skills in the learner. [2] recomends to redesign instructional strategies for generic skills. In line to their recomendation, this study redesign intructional strategies with epitome, teaching technique, teaching method and decriptive hypotheis. [3] concludes that whilst there were significant six areas of commonality amongst the frameworks, regional differences were also apparent. Related to the findings of [4] this study focus on contruct of ELT method and techniqs directly related to generic teaching skills and descriptive hypothesis to test it. Acoding to [5] schools textbook are not conductive to CLT implementation, private institute textbooks represent the CLT principles to a great extent. This research anticipates such a gap. With the formulation of descriptive hypothesis, teacher in classroom orient leaning and aquisition as a step by step process to accomodate communicative practices and goal. [6] found out the Malaysian epitome such as citizenship, honesty, passion, knowledge transfer, critical thinking, perseverance. However this studies is about Indonesian Epitome that states strong Indonesian sutainable nationality must be rooted on grounded global international understanding through English communication.

Teaching according to [7] the $1^{\text {st }}$ Principle of Instruction is - $\mathrm{A}=\mathrm{f}[\mathrm{I}]$ ( $\mathrm{A}=$ learning outcomes, learner's achievement; $\mathrm{f}=$ function; I = instruction) .how does s/he know if he has completed the lecture enterprise in scientitific evidence?. The hard core of education is the epitome -- how ELT princples and subjcts put in action, how to get things done in English, acquisition in the process of learning by doing, doing by learning, learning teaching by doing, and doing teaching by learning. Then, the process become sets of ELT treatment, how candidate teachers in doing teaching practice and acquire empowerment for revitalization and reinforcement of their skills in doing learning and teaching, and to test its descriptive hypothesis.

In line with the first principle of instruction, $a=f(I)$, this research is to examine how a descriptive hypothesis as teaching learning acts works or not. By instruction, it elaborates how a lecturer develops the learning-teachinglearning in epitome in ELT, and addresses itself to learning outcomes. In short, it settles the instructional process as to how a teacher test ELT descriptive hypothesis in classroom. It practically matters with an epitome construct of ELT and how the lecture help empower the learner to develop its praxis, demonstration, discussion, conference and teaching practices on ELT simulation, mini-teaching and microteaching. To what extent has the lecture/the teaching with its epitome construct has successfully proved its ELT descriptive hypothesis significance? The questions is as follows: Is there a significant difference between preassessment and post test in each episodes, between experiment groups and control groups, and the experimental groups shows better in realizing ELT generic skills in in descriptive hypothesis test their teaching. 
The purpose is to test teaching hypothesis, how its empowerment in particular to process CAR experiment for ELT candidates in the processes of revitalization and reinforcement to acquire generic teaching skills and to test it with descriptive hypothesis. What the teacher is doing and why he is doing what he is doing.

\section{ELT PEDAGOGY}

How is the ELT state of the arts today? For the last decade, ELT search the enterprise for praxis. [8] said that the philosophy and principles of second language are rooted firmly in the field of general education. As language teachers, we are a branch on a much larger tree, and our professional lives will be immeasurably enriched if we are knowledable about the rest of the tree. Putting Nunnan's sentencia in ELT, Browsing ELT methods lead the matters at least to some praxis as classroom, pedagogy, general pedagogy and the educational state of the arts. The core reflecting what ELT teachers are doing and why they are doing what they are doing-the state of the arts.In principles any teaching enterprise constitute an epitome how it in action. [9] states that CLT can make English teaching effective and meaningfull. This research accomodate this principles in ELT descriptive hypothesis and experiment if the hypothesis is sutainable or not.

Descrivtive hypothesis is a teaching hypothesis. [10]. [11]. [12] reports from Socrates' unexamined life is not worth doing to now "what is professional worth-doing in the realm of ELT the state of the arts, from what ELT classrooms are doing, what ELT pedagogy they keep as principles, what school of pedagogy, and how is the present.

Teaching is a an epitome [13], an epitome of tour of duty for as the essence of science and its value. The true value of a human being is determined primarily by the measure and the sense in which they have obtained liberation from the self. For long, teaching mostly matters learning output than learning outcomes. Besides, pedagogical aspects are less concerned. It is a complex phenomeonis moredoing for global literacy, particularly in developing teaching as a scientific enerprises. In this a teacher is to know, the explicit knowledge of teaching, the teaching epitome, its structure, [14], the what's and the how's of ELT. It is the teaching learning acquisition process in ELT either based on a given method or from a more general pedagogy, [15] and overall the ELT.

\section{A. Praxus-1: ELT Classroom Communicative Competence}

Teaching today is directed to future students, principles of relevance, student's communicative competence.In grade- Oup to grade-12 teaching generic English competenciesconstitute language as character, that is, communicating is doing a character how to get things done. The concern for classroom teachersis to test whether their teachinghs substantially scientific.

\section{B. Paxsis-2: ELT Classroom Pedagogy}

Pedagogy is the standard of good practice, doing the enterprise that learners are enjoying learning.Its epitome of teaching is to do a circular dialectical concern upon its value, that is, the essence of language literacy and world life upon how the language communicative competence becomesessence of worth life in the future. Getting things done in language speech acts matter the learning outcomes. The learning outcomes are expected productive in business world, from the learner's self quality to his communicative performance power. In European language education, the demand is subsumed as generic communicative competence, [16].

\section{ELT Pedagogy and Generic Matter}

[17] mention five generic core of as epitome in ELT pedagogy for praxis and English Education, as Goal, Communicative Competence, Pedagogy, classroom gain and assessment, even at the policy level. For Indonesia, ELT functions to enhance international world as the source of reference for international undersanding according to [18]. For classroom praxis, [19] recommend twelve communicative thresholds, as follows: 1) Establishing and maintaining social relations, 2) seeking information, 3) giving information (about oneself, a well-known sebject,etc), 4). Learning to do to make something, 5). Expressing reactions: to a TV show, movie, slide-presentation, 6). Hiding one's intentions from others, 7). Talking one's way out of trouble, 8). Problem-solving, 9).Sharing leisure activities, 10). Connecting on the telephones, 11). Entertaining, 12).Displaying one's achievements.

Learning a foreign language is foreign. To substantiate generic communicative beach head, students gains first competency in linguistic beach head, how to enter the foreign English by functioning the language tool proper according to [20]. It is doing English prime simple communicative capacity in the beginning. For learning outcomes, all these will be substantiated in Indonesian English classroom as Level-2 to get things done in 2013 English curriculum for Grade- 0 up to Grade-12 whereas for candidate ELT as Level-6: to do functionally an ELT paradigm-in-classroom-praxis.

\section{Praxis-4 Broder Educational Pedagogy}

In its very core, teaching English teacher is a value to put into praxis. The question is the core competency as epitome, is an ELT teacher as intellectual capacity to define, solve and make resolution to a problem.

\section{E. Epitome with Generic Teaching and Descriptive Hypothesis}

Along his life tendure in education, after three decades of the enterprise, [21] in the end launched epitome, generic skills, prescriptive hypothesis and descriptive hypothesisas constructs substantive to test teaching hypotheis as a science of teaching. Epitome become the values and essence of education like tractacusin Wittsgenstein in semiotics. It functions as an embracing principle how a teacher match ELT to learning outcomes for the learner. Prescriptive hypothesis is for a given teaching set in one period, the teacher write a hypothesis to test if it is sustainable. Descriptive is more discrete hypothesis to test one teaching or one unit teaching.

To develop a framework for descriptive hypotheses for ELT, this research follows the first principle of instruction is $\mathrm{A}=\mathrm{f} \quad[\mathrm{I}]$ (A = learning outcomes, learner's achievement; $\mathrm{f}=$ function; I = instruction). [22] states within this principles any 
instructor in their instructional design launched their vision, that is generic skill as a common body of knowledge and Instructional approach. Overall the Instructional design and description covers its content layers, strategy layers, message layers, control layers, representation layers, media-logic layers and data management layers, [23].

TABLE I. EPITOME WITH GENERIC TEACHING AND DESCRIPTIVE HYPOTHESIS

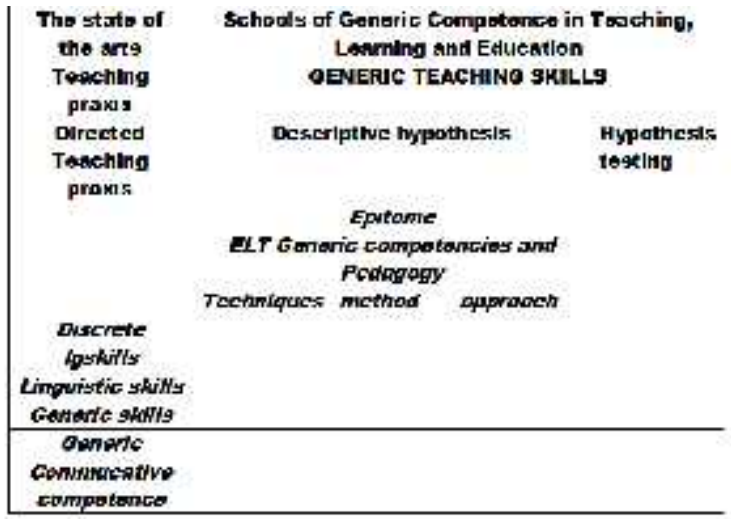

The matter today is language competency as the output as well as the out comes (Table 6). In language teaching the competencies to develop the rubric a,b,c (mager 1980), how to develop a teaching constract in pedagogical contruct as follows:

a. Learners (recomended by [24] one descriptive hypothesis)

b. Competency

c. Total pedagogy as total acts

d. level of competency

Example: descritive hypothesis 1

a. student defnes their descriptive hypothesis in a lesson plan, descriptive hypothesis, Grade-11 " by doing, demonstrating and participative training in suggestopedia and total physical response, the students rehearse public speaking model of either John F Kennedy or Bung Karno in classroom performance."

b. Student defines their microteaching goals in a descriptive hypothesis statement, by training step-1 upto-step10, students demonstrate a story about "my Daddy, my Mom, my School", etc as a story telling.

For competency praxis, students follow the generic paradigm roadmap below to formulate generic communicative competence as their teaching competency goal.

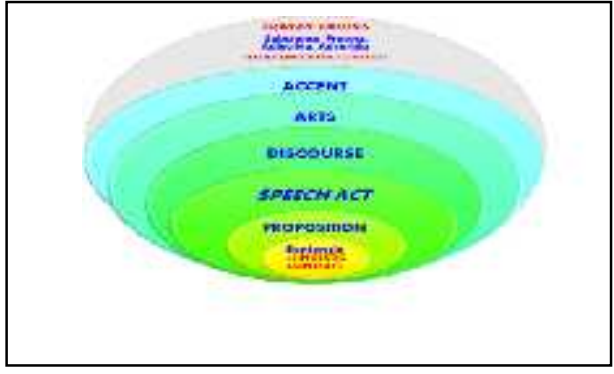

Fig. 1. Demand on Generic Competency

\section{EXPERIMENT UPON TRANSFORMATIVE EMPOWERMENT: CAR IN CYCLES}

Though sharing a number of perspectives with the interpretive paradigm, and making considerable use of its related qualitative methodologies, there are some researchers who feel that neither it nor the positivist paradigms are sufficient epistemological structures under which to place action research [25], [26]. Rather, a paradigm of Praxis is seen as where the main affinities lie. Praxis, a term used by Aristotle, is the art of acting upon the conditions one faces in order to change them. It deals with the disciplines and activities predominant in the ethical and political lives of people. Aristotle contrasted this with Theoria- those sciences and activities that are concerned with knowing for its own sake. Both are equally needed he thought. That knowledge is derived from practice, and practice informed by knowledge, in an ongoing process, is a cornerstone of action research. Action researchers also reject the notion of researcher neutrality, understanding that the most active researcher is often one who has most at stake in resolving a problematic situation.

\section{FINDINGS}

The first principle of instruction is $A=f \quad[I](A=$ learning outcomes, learner's achievement; $\mathrm{f}=$ function; $\mathrm{I}=$ instruction) is veriable with descriptive hyopothesis. The hypothesis being tested: Descriptive $\mathrm{H}_{01}$, There is no siginificant difference in the instructional outcomes between pretest and post-assessment in control and experimental groups. Descriptive $\mathrm{H}_{02}$, There is no siginificant difference in the instructionl outcomes between the Experimental Group1 and the control group. Descriptive $\mathrm{H}_{03}$, There is no siginificant difference in the instructionl outcomes between the Experimental Group2 and the control group. Descriptive $\mathrm{H}_{04}$, There is no siginificant difference in the instructionl outcomes between the Experimental Group3 and the control group. Descriptive $\mathrm{H}_{05}$, There is no siginificant difference in the instructionl outcomes between the Experimental Group1,2,3 and the control group.

There is no siginificant difference in the instructional outcomes between pretest and post-assessment in control and experimental groups. Comparing three experimental class with control class at pretest_post_test across the episodes in control and experimental groups upon significance difference.

TABLE II. FINDINGS

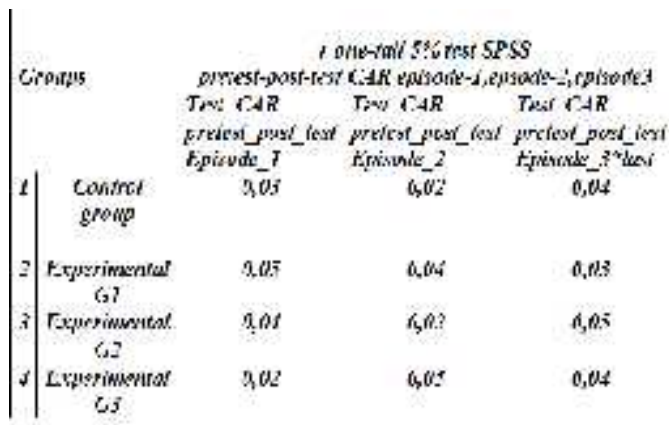

The $\mathrm{H}_{01}$ is rejected. From the T-Test in general there is a significant difference in each episode between preassessment 
and post assessment in each episodes 1, 2, 3 in the CAR cycles at $5 \%$ siginificance.

\section{A. Comparing Experiment and Control Group}

Descriptive $\mathrm{H}_{02}$, There is no siginificant difference in the instructionl outcomes between the Experimental Group-1 and the control group.

TABLE III One Sample Statistics

\begin{tabular}{|l|l|l|l|l|}
\hline & $\mathrm{N}$ & Mean & Std. Deviation & Std. Error Mean \\
\hline VAR00001 & 38 & 47.8596 & 3.97487 & .64481 \\
VAR00002 & 39 & 56.9231 & 1.51109 & .24197 \\
\hline
\end{tabular}

TABLE IV ONE--SAMPLE TEST

\begin{tabular}{|c|c|c|c|c|c|c|}
\hline & \multicolumn{6}{|c|}{ Test Value $=0$} \\
\hline & \multirow[b]{2}{*}{$\mathrm{t}$} & \multirow[b]{2}{*}{ df } & \multirow[b]{2}{*}{ Sig. (2-tailed) } & \multirow[b]{2}{*}{ Mean Difference } & \multicolumn{2}{|c|}{$\begin{array}{l}95 \% \text { Confidence Interval of the } \\
\text { Difference }\end{array}$} \\
\hline & & & & & Lower & Upper \\
\hline VAR00001 & 74.223 & 37 & $.0,03$ & 47.85965 & 46.5531 & 49.1662 \\
\hline VAR00002 & 235.250 & 38 & 0,03 & 56.92308 & 56.4332 & 57.4129 \\
\hline
\end{tabular}

The $\mathrm{H}_{02}$ is rejected. From the T-Test in general there is a significant difference between experimental and control groups in each episode between preassessment and post assessment in each episodes 1,2 , and 3 at $5 \%$ siginificance.

TABLE V. One-Sample Statistics

\begin{tabular}{|c|c|c|c|c|}
\hline & $\mathrm{N}$ & Mean & Std. Deviation & Std. Error Mean \\
\hline VAR00001 & 38 & 47.8596 & 3.97487 & .64481 \\
VAR00003 & 24 & 69.7917 & 3.64726 & .74449 \\
\hline
\end{tabular}

TABLE VI. One-Sample Test

\begin{tabular}{|c|c|c|c|c|c|c|}
\hline & \multicolumn{6}{|c|}{ Test Value $=0$} \\
\hline & \multirow[b]{2}{*}{$\mathrm{t}$} & \multirow[b]{2}{*}{ df } & \multirow[b]{2}{*}{ Sig. (2-tailed) } & \multirow[b]{2}{*}{ Mean Difference } & \multicolumn{2}{|c|}{$\begin{array}{l}95 \% \text { Confidence Interval of the } \\
\text { Difference }\end{array}$} \\
\hline & & & & & Lower & Upper \\
\hline VAR00001 & 74.223 & 37 & .000 & 47.85965 & 46.5531 & 49.1662 \\
\hline VAR00003 & 93.744 & 23 & .000 & 69.79167 & 68.2516 & 71.3318 \\
\hline
\end{tabular}

The $\mathrm{H}_{01}$ is rejected. From the T-Test in general there is a significant differencebetween experimental and control groups in each episode between preassessment and post assessment in

Descriptive $\mathrm{H}_{04}$, There is no siginificant difference in the instructionl outcomes between the Experimental Group3 and the control group. each episodes 1,2 and 3 at $5 \%$ siginificance.

TABLE VII. One-Sample Statistics

\begin{tabular}{|l|l|l|l|l|}
\hline & $\mathrm{N}$ & Mean & Std. Deviation & Std. Error Mean \\
\hline VAR00001 & 38 & 47.8596 & 3.97487 & .64481 \\
VAR00004 & 45 & 60.2778 & .79693 & .11880 \\
\hline
\end{tabular}


TABLE VIII. One-Sample Test

\begin{tabular}{|c|c|c|c|c|c|c|}
\hline & \multicolumn{6}{|c|}{ Test Value $=0$} \\
\hline & \multirow[b]{2}{*}{$\mathrm{t}$} & \multirow[b]{2}{*}{ df } & \multirow[b]{2}{*}{ Sig. (2-tailed) } & \multirow[b]{2}{*}{ Mean Difference } & \multicolumn{2}{|c|}{$\begin{array}{l}95 \% \text { Confidence Interval of the } \\
\text { Difference }\end{array}$} \\
\hline & & & & & Lower & Upper \\
\hline VAR00001 & 74.223 & 37 & .000 & 47.85965 & 46.5531 & 49.1662 \\
\hline VAR00004 & 507.390 & 44 & .000 & 60.27778 & 60.0384 & 60.5172 \\
\hline
\end{tabular}

The $\mathrm{H}_{04}$ is rejected.From the $\mathrm{T}$-Test in general there is a significant difference between experimental and control groups in each episode between preassessment and post assessment in each episodes 1,2 and 3 at 5\% siginificance.

\section{B. Comparing Total Experiment 1,2,3 VS Control Group}

Descriptive $\mathrm{H}_{05}$, There is no siginificant difference in the instructionl outcomes between the experimental Group1,2,3 and the control group.

TABLE IX One-Sample Statistics

\begin{tabular}{|l|l|l|l|l|}
\hline & $\mathrm{N}$ & Mean & Std. Deviation & Std. Error Mean \\
\hline VAR00001 & 38 & 47.8596 & 3.97487 & .64481 \\
VAR00005 & 24 & 62.0000 & 1.33474 & .27245 \\
\hline
\end{tabular}

TABLE X. One-Sample Test

\begin{tabular}{|c|c|c|c|c|c|c|}
\hline & \multicolumn{6}{|c|}{ Test Value $=0$} \\
\hline & \multirow[b]{2}{*}{$\mathrm{t}$} & \multirow[b]{2}{*}{$\mathrm{df}$} & \multirow[b]{2}{*}{ Sig. (2-tailed) } & \multirow[b]{2}{*}{ Mean Difference } & \multicolumn{2}{|c|}{$\begin{array}{l}95 \% \text { Confidence Interval of the } \\
\text { Difference }\end{array}$} \\
\hline & & & & & Lower & Upper \\
\hline VAR00001 & 74.223 & 37 & .000 & 47.85965 & 46.5531 & 49.1662 \\
\hline VAR00005 & 227.562 & 23 & .000 & 62.00000 & 61.4364 & 62.5636 \\
\hline
\end{tabular}

The $\mathrm{H}_{05}$ is rejected. From the T-Test in general there is a significant difference between experimental and control groupsin each episode between preassessment and post assessment in each episodes 1, 2, 3at 5\% siginificance.

\section{DISCUSSION}

Teaching overall may apply the first principle of instruction is $\mathrm{A}=\mathrm{f} \quad[\mathrm{I}]$ ( $\mathrm{A}=$ learning outcomes, learner's achievement; $\mathrm{f}=$ function; $\mathrm{I}=$ instruction) to test if their deliveries and tuor of duty function with empirical evidence on teaching. This principle is stated in ELT descriptive hypothesis. During the process of hypotheis formulation, it takes strugle and reflection for the learners to arrive at a better hypothesis statement. The experimental process in the learners as candidate teachers always face barriers in one or the other aspect of the generic teaching skills suach as the meaning as to what eanglishes for, and techniques to accomplishes such performance. Meanwhile, the epitome, generic skills, prescriptive hypothesis and descriptive hypothesis will subsumes instructional constituents as the teaching roadmap overall the subjects. The narrative episodes of teaching and learning stages will function as core pedagogic acts in realizing in classroom praxis overall in what the are doing. Doing teaching and lecturing is doing a subject over its matters. Philosophically it is a goal-means-end analysis, in a problem-solving perspective. Crises in teaching and learning commences in the very real classroom.

The true value of a human being is determined primarily by the measure and the sense in which they have obtained liberation from the self....We shall require a substantially new manner of thinking if humanity is to survive. [27]. Teachers and lectrers are now challenged to show empirical evidence upon their teaching and learning, the tour of duty.

\section{ACKNOWLEDGMENT}

The researcher would like to deliver a great thaks to KEMENRISTEKDIKTI for the fund based on the number SP DIPA-042.06.1.401516/2018 which really helpful to conduct this reaserch. 


\section{REFERENCES}

[1] Frison et.al. "Work-related Teaching and Learning Methods to Foster Generic Skills in Higher Education.An Italian experience". Tuning Journal for Higher Education.2016, vol 4, no. 2, pp. 145-167

[2] Sigh and Gera, "Developing Generic Skills in Higher Education". Indian Journal of Applied Research.2015, vol 5, no. 6, pp. 824-825.

[3] Young and Chapmen, " Generic Competency Frameworks: A Brief Historical Overview". Educational Research and Perspectives. 2010 Vol. 37, No.1, pp. 1-24.

[4] Young and Chapmen, " Generic Competency Frameworks: A Brief Historical Overview”. Educational Research and Perspectives. 2010 Vol. 37, No.1, pp. 1-24.

[5] Razmjoo, S,A. "High Schools or private institutes textbooks? Which fulfillment communicative language teaching principles in the Iranian Context?". Asian EFL Journal, 2007 Vol 9 No 4, pp. 126-140

[6] Salleh and Soosay (2016), "How to Master Generic Skills in the English Language? An Electronic-Problem-Based Learning Way: A Malaysian Experience. IJAEDU.2016 Vol 2, No 5, pp. 227-233.

[7] Reigeluth, C. M. Instructional theory for education in the information age.In C. M. 2009

[8] Nunan, David. Second Language Teaching \& Learning. Boston: Heinle\&Heinle Publishers. 1999

[9] Chang,M. "EFL Teachers' Attitude toward communication language Teaching in Taiwanese College". Asian EF, 2011 Vol.53, pp. 17-34.

[10] Reigeluth, C. M. "The search for meaningful reform: A third-wave educational system". Journal of Instructional Development, 1987 Vol 10 No.4, pp. 3-14.

[11] Reigluth, Charless, Volume I Instructional Design Theories and Models, 1983.

[12] Reigeluth, Volume II Instructional Design Theories and Models (New Paradigm), 1999

[13] Reigeluth, C. M. "The search for meaningful reform: A third-wave educational system." Journal of Instructional Development, 1987, Vol 10 No. 4, pp. 3-14.

[14] Reigluth, Charless, Volume I Instructional Design Theories and Models, 1983

[15] Nunnan, David, Second Language Learning and Teaching, USA Heinle\&Heinle Publishers. 1999

[16] Sanches, Aurelo Villa\& Ruiz, Manuel Poblete, Competence Based Learning, Unicersity of Deusto, 2008.

[17] Rivers, Wilga M, Teaching Foreign Language Skills, Ann Arbor, The University of Michigan Press. Michicgan. 1972.

[18] Rivers, Wilga M, Teaching Foreign Language Skills, Ann Arbor, The University of Michigan Press. Michicgan. 1972.

[19] Rivers, Wilga M, Teaching Foreign Language Skills, Ann Arbor, The University of Michigan Press. Michicgan. 1972.

[20] Carr, W. \&Kemmis, S. Becoming Critical: education, knowledge and action research. Lewes, Falmer. 1986

[21] Reigeluth, Vol I (1983), "Instructional Design Theories and Models, Roulete, Taylor \& Francis Publishers, New York. Vol II (1999) Instructional Design Theories and Models," Roulete, Taylor \& Francis Publishers, New York. Vol III (2009)

[22] Reigeluth, Volume II Instructional Design Theories and Models (New Paradigm), 1999

[23] Reigeluth, Volume II Instructional Design Theories and Models (New Paradigm), 1999

[24] Reigeluth, Volume II Instructional Design Theories and Models (New Paradigm), 1999

[25] Robert Cowen and Andre Azamias, International Handbook of Comparative education, Springer. 2009.

[26] Reigeluth, C. M. (2011).An instructional theory for the post-industrial age.Educational Technology, 2011. Vol 51No 5, pp. 25-29.

[27] Reigeluth, C. M. ".Instructional theory and technology for a postindustrial world.” In R. A. Reiser\& J. V. Dempsey (Eds.), Trends and issues in instructional design and technology 2012. 3rd ed., pp. 75-83). Boston: Pearson Education. 